\title{
Anvirzel $^{\mathrm{TM}}$ in combination with cisplatin in breast, colon, lung, prostate, melanoma and pancreatic cancer cell lines
}

\author{
Panagiotis Apostolou', Maria Toloudi ${ }^{1}$, Marina Chatziioannou' ${ }^{1}$, Eleni loannou ${ }^{1}$, Dennis R Knocke ${ }^{2}$, Joe Nester ${ }^{2}$, \\ Dimitrios Komiotis ${ }^{3}$ and loannis Papasotiriou ${ }^{1 *}$
}

\begin{abstract}
Background: Platinum derivatives are used widely for the treatment of many cancers. However, the toxicity that is observed makes imperative the need for new drugs, or new combinations. Anvirzel ${ }^{\mathrm{TM}}$ is an extract which has been demonstrated with experimental data that displays anticancer activity. The aim of the present study is to determine whether the combination of Cisplatin and Anvirzel $^{\mathrm{TM}}$ has a synergistic effect against different types of cancer.

Materials and methods: To measure the efficacy of treatment with Cisplatin and Anvirzel ${ }^{\mathrm{TM}}$, methyl-tetrazolium dye (MTT) chemosensitivity assays were used incorporating established human cancer cell lines. Measurements were performed in triplicates, three times, using different incubation times and different concentrations of the two formulations in combination or on their own. t-test was used for statistical analysis.

Results: In the majority of the cell lines tested, lower concentrations of Anvirzel ${ }^{\mathrm{TM}}$ induced a synergistic effect when combined with low concentrations of Cisplatin after an incubation period of 48 to $72 \mathrm{~h}$. The combination of Anvirze $^{\mathrm{TM}} /$ Cisplatin showed anti-proliferative effects against a wide range of tumours.

Conclusion: The results showed that the combination of Anvirzel ${ }^{\mathrm{TM}}$ and Cisplatin is more effective than monotherapy, even when administered at low concentrations; thus, undesirable toxic effects can be avoided.
\end{abstract}

Keywords: Anvirzel ${ }^{\mathrm{TM}}$, Cisplatin, Viability assays, Cancer cell lines, Methyl-tetrazolium dye

\section{Background}

Many studies demonstrate the anti-proliferative activity of Oleandrin. These properties make it attractive for use as a treatment for cancer [1-5]; however, a major problem is that Oleandrin is toxic to normal cells and tissues $[6,7]$. Anvirzel ${ }^{\mathrm{TM}}$ is an extract of Nerium oleander comprised primarily of Oleandrin and Oleandrigenin [8]. Recent studies demonstrate that Anvirzel $^{\mathrm{TM}}$ decreases viability in prostate cancer cell lines as well as a wide range of other human cancer cell lines [9-12]. Cisplatin (CDDP) is a platinum-based chemotherapy drug used to treat various types of cancer $[13,14]$. Because it is highly toxic, and because of primary and secondary resistance of cancer cells to Cisplatin [15], it is commonly used in combination with other drugs $[16,17]$. A recent study

\footnotetext{
* Correspondence: papasotiriou.ioannis@rgcc-genlab.com

${ }^{1}$ Research Genetic Cancer Centre Ltd (R.G.C.C. Ltd), Filotas, Florina, Greece

Full list of author information is available at the end of the article
}

reported that the combination of Anvirzel ${ }^{\mathrm{TM}}$, Carboplatin and Docetaxel is more effective than monotherapy [18]. Therefore, the aim of the current study was to determine whether the combination of Anvirzel ${ }^{\mathrm{TM}}$ and Cisplatin was more effective than the use of either drug alone using MTT chemosensitivity assays based on human cancer cell lines [19-23].

\section{Methods}

The human carcinoma cell lines used were obtained from the ECACC-HPA (European Collection of Cell Cultures - Health Protective Agency, UK). PC3, LNCaP and 22Rv1 are human prostate cancer cell lines, MDAMB 231, T47D, and MCF-7 are human breast cancer lines, CALU-1, COLO699N and COR-L 105 are nonsmall cell lung carcinoma lines (NSCLC), HCT-116, HT55 and HCT-15 are colorectal cancer lines, and A375 and PANC-1 are melanoma and pancreatic cancer cells

\section{Biomed Central}




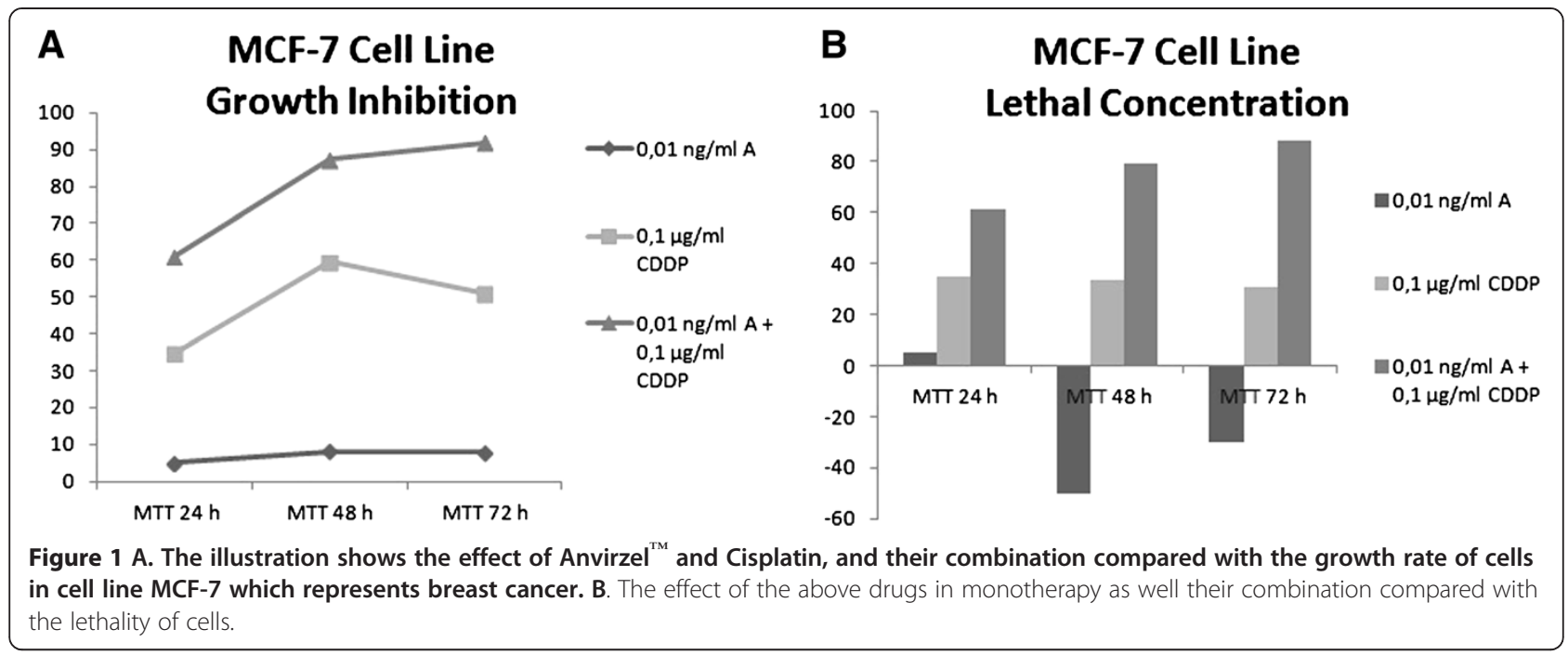

lines, respectively. MTT chemosensitivity assays were used to determine the efficacy of combined treatment compared with that each drug alone. The incubation times used in the study were 24,48 and $72 \mathrm{~h}$ at concentrations ranging from $0.01 \mathrm{ng} / \mathrm{ml}$ to $10 \mathrm{ng} / \mathrm{ml}$ for Anvirzel ${ }^{\mathrm{TM}}$ and from $0.1 \mu \mathrm{g} / \mathrm{ml}$ to $100 \mu \mathrm{g} / \mathrm{ml}$ for Cisplatin.

\section{Cell lines}

Cells were cultured in $75 \mathrm{~cm}^{2}$ flasks (Orange Scientific, $5520200)$ in the recommended media supplemented with the appropriate amount of heat inactivated Fetal Bovine Serum (FBS, Invitrogen, 10106-169, California) and $2 \mathrm{mM} \mathrm{L-Glutamine} \mathrm{(Sigma,} \mathrm{G5792,} \mathrm{Germany).} \mathrm{The}$ cells were maintained at $37^{\circ} \mathrm{C}$ in a $5 \% \mathrm{CO}_{2}$ atmosphere.

Viability assays

Cells were detached by trypsinisation (Trypsin-0.25\% EDTA, Invitrogen, 25200-072) during the logarithmic phase of growth and plated in 96-well plates (Corning, Costar 3595) at a density of 18,000 cells/well in a final volume of $200 \mu \mathrm{l}$ medium per well. When the cells reached $70-80 \%$ confluence, the medium was removed and Anvirzel ${ }^{\mathrm{TM}}$ (Salud Integral; diluted in water) and Cisplatin (Sigma, P4394; diluted in N, N-dimethylformamide; Fluka, 40255) were added to the cells at different concentrations. Absorbance was measured after 24, 48 and $72 \mathrm{~h}$ of incubation.

\section{MTT assay}

For the MTT assay, methyl-tetrazolium dye (Sigma, M2128) was added to each well at a concentration of $5 \mathrm{mg} / \mathrm{ml}$ (diluted in PBS) and the plates incubated for $3 \mathrm{~h}$ at $37^{\circ} \mathrm{C}$. The medium was then discarded and the cells rinsed with PBS. Finally, the formazan crystals were dissolved in dimethylsulphoxide (Sigma, D4540).

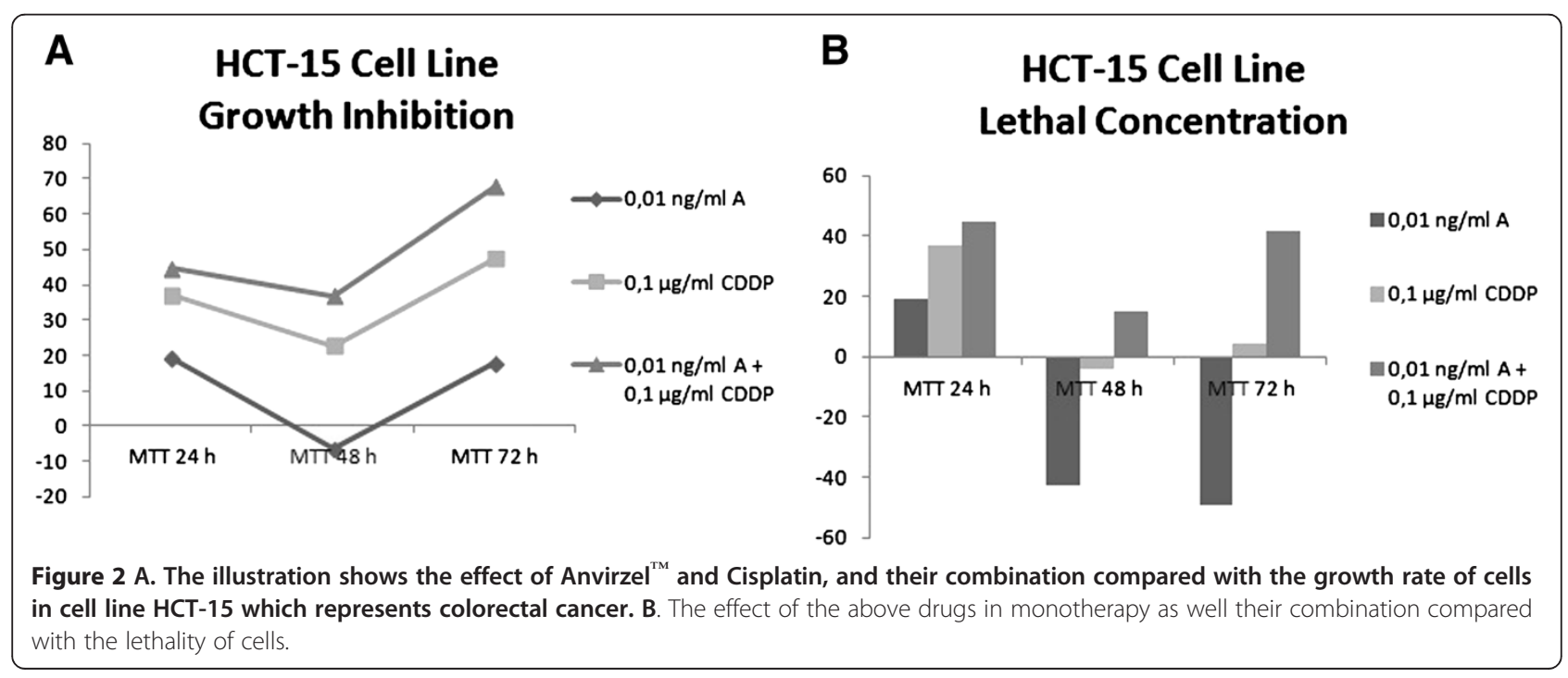




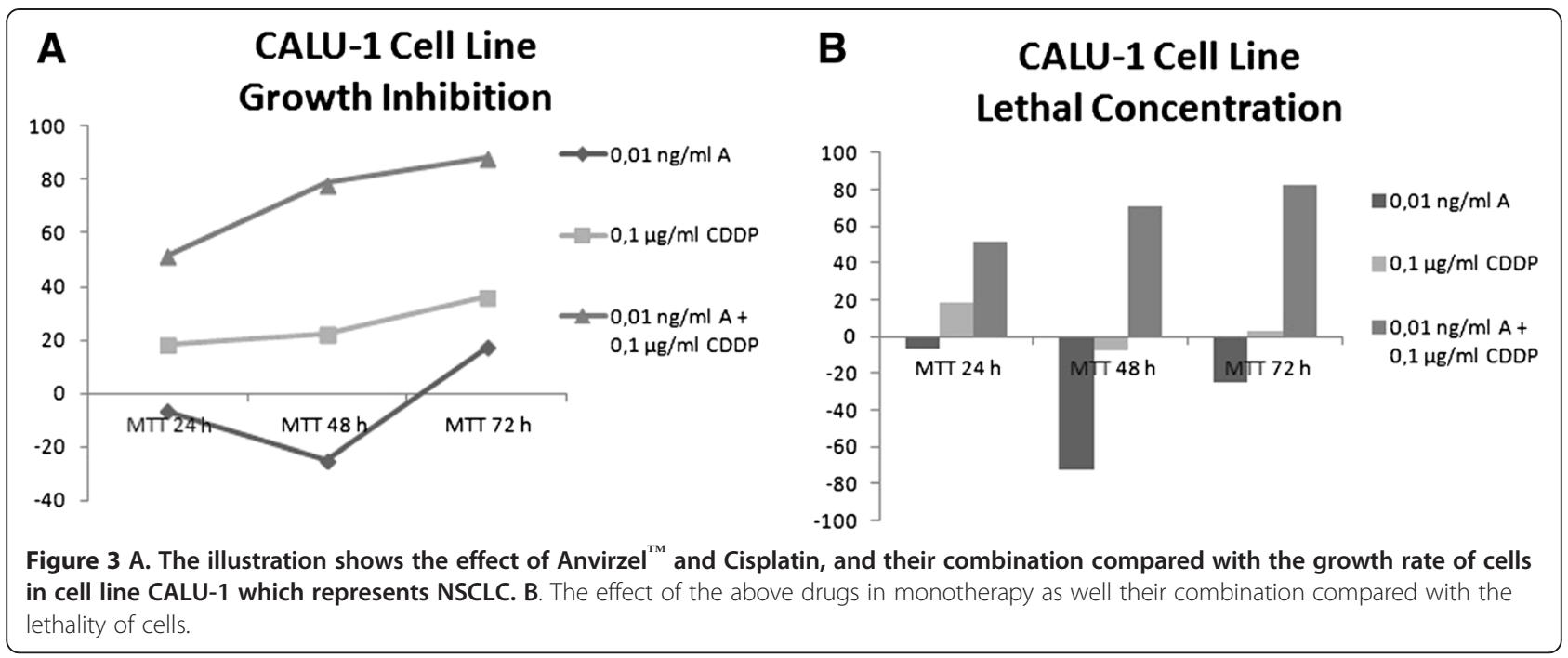

To calculate the fold-decrease in staining the absorbance was calculated using the Beer-Lambert law: $\mathrm{A}=\varepsilon \mathrm{cl}$, where " $A$ " is the absorbance, " $\varepsilon$ " is an extinction coefficient, "l" is the distance the light travels through the material, and " $\mathrm{c}$ " is the concentration of the absorbing species [24].

The optical density of the plate was measured using a $\mu$ Quant spectrophotometer ( $\mu$ Quant Biomolecular Spectrophotometer MQX200) and the data analysed with Gen5 software $\left(\mathrm{Gen}^{\mathrm{TM}}{ }^{\mathrm{M}}\right.$ Microplate Data Collection \& Analysis software, BioTek ${ }^{\circledR}$ Instruments. Inc, April 2008). Absorbance was measured at $570 \mathrm{~nm}$ and a second wavelength at $630 \mathrm{~nm}$ was measured to subtract background "noise".

\section{Statistical analysis}

All treatments for each cell line were performed in triplicate, three times. The statistical significance of all effects was evaluated using the "difference of the means" test. A p value $<0.05$ was considered significant.

\section{Results}

Different results were observed not only between each type of cancer but also between each cell line within the same carcinoma group. In all cell lines has been studied LC50 (lethal concentration 50), which is the concentration that kill half of the sample population, and GI50 (growth inhibition 50), which is the concentration required to inhibit growth by $50 \%$. In all cell lines tested, administration of the combined formulation at lower concentrations was more effective than monotherapy. The formulation that elicited the most effective results in most of the cell lines was a combination of $0.01 \mathrm{ng} /$ $\mathrm{ml} \mathrm{Anvirzel}{ }^{\mathrm{TM}}$ and $0.1 \mu \mathrm{g} / \mathrm{ml}$ Cisplatin, with incubation period of $48 \mathrm{~h}$ or $72 \mathrm{~h}$. The combination of $0.01 \mathrm{ng} / \mathrm{ml}$ Anvirzel $^{\mathrm{TM}}$ and $1 \mu \mathrm{g} / \mathrm{ml}$ Cisplatin was more effective in

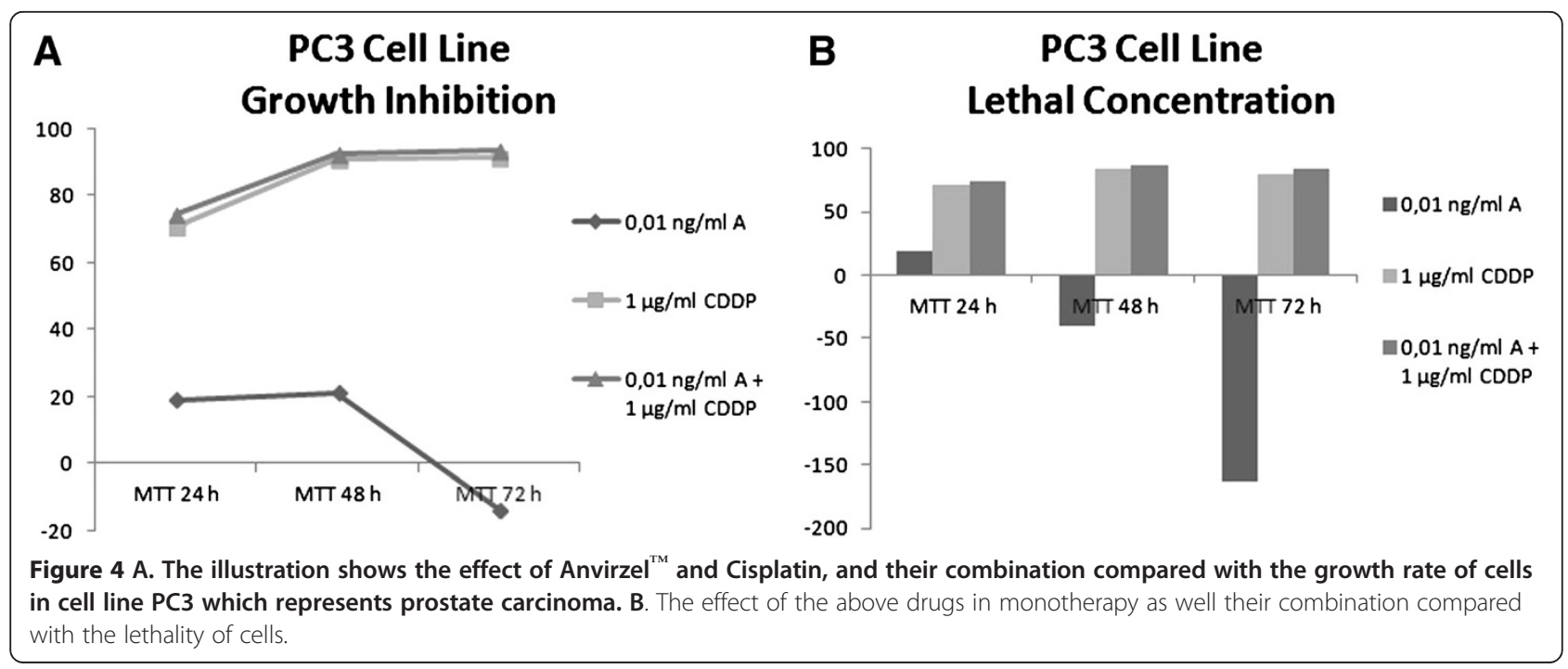




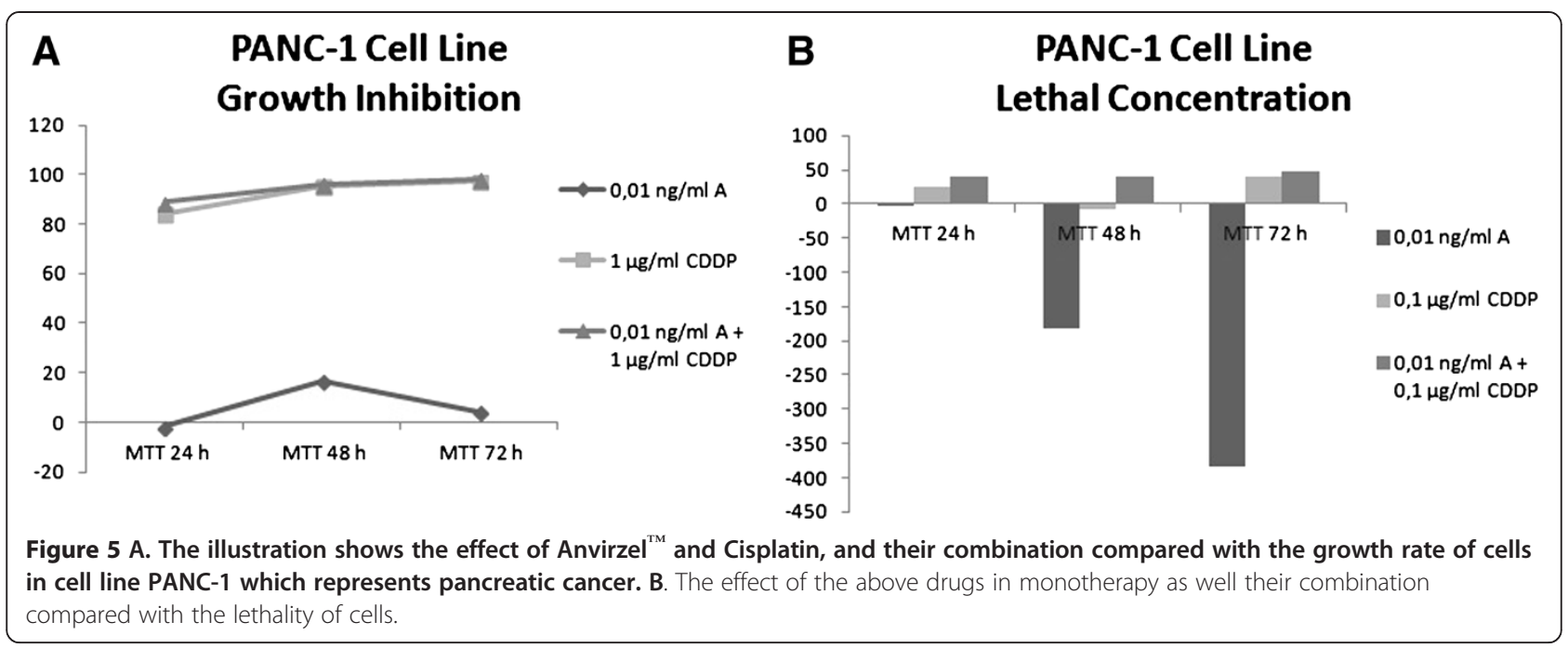

pancreatic cancer cell line, as well in PC3 and MDAMB231 cell lines. The Figures 1, 2, 3, 4, 5, 6 represent data from cell lines that were tested both for Growth inhibition and for Lethal Concentrations.

\section{Discussion}

Anvirzel $^{\mathrm{TM}}$ is an extract of Nerium oleander (family Apocynaceae) that contains two toxic cardiac glycosides, Oleandrin and Oleandrigenin [8], which have antiproliferative effects against various types of cancer. According to literature data, Nerium oleander is often used for its healing properties [25]. Oleandrin is used to treat heart failure, and alters the levels of intracellular $\mathrm{K}^{+}$and $\mathrm{Ca}^{2+}[26]$. Other studies show that Oleandrin suppresses the activation of many transcription factors and enhances the radiosensitivity of tumours $[27,28]$. Oleandrin induces cell death through the activation of caspases in a variety of human tumour cells, as well as by activating calcineurin and NF-AT via the Fas ligand [3]. Recent studies of Anvirzel ${ }^{\mathrm{TM}}$ in prostate cell lines show that it interacts with the membrane $\mathrm{Na}^{+} / \mathrm{K}^{+}$ATPase and thus inhibits the export of FGF-2 [11,28]. Cisplatin is a platinum-based chemotherapy drug widely used to treat various types of cancer [13,14]. In high concentrations, Cisplatin is highly cytotoxic. In addition, tumour cells often develop resistance to treatment [15]. Many studies demonstrate that administration of Cisplatin in combination with other treatments is more effective and produces fewer toxic effects. The present study aimed the demonstrate the synergistic effect of Anvirzel $^{\mathrm{TM}}$ and Cisplatin in a wide range of cell lines, which represent the most common types of cancer. It was used the methyl-tetrazolium dye assay, which is used to measure the activity of enzymes in the mitochondria.

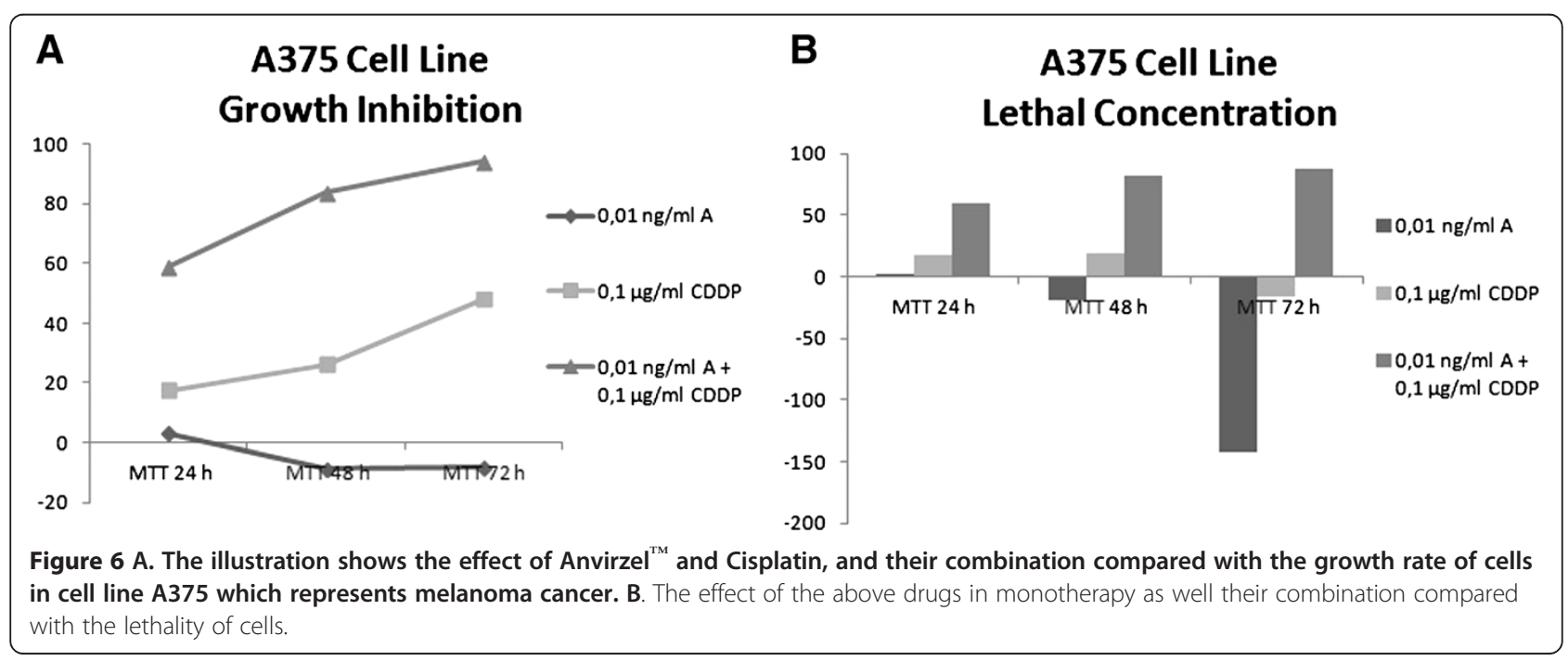


During this assay, the dye is taken up by endocytosis and reduced by the mitochondrial enzymes to yield formazan, which is purple/blue $[19,20]$.

It has been confirmed that Anvirzel ${ }^{\mathrm{TM}}$ has better activity at lower concentrations in many cancer cell lines, after 48 or $72 \mathrm{~h}$ of incubation. In contrast, low Cisplatin concentrations $(<1 \mu \mathrm{g} / \mathrm{ml})$, do not indicate activity in the same cells. The effect of platinum is evident at concentrations greater than $10 \mu \mathrm{g} / \mathrm{ml}$. However, these concentrations have high cytotoxicity effects. The combination of the two formulations at very low concentrations is able to inhibit cell growth by more than $50 \%$ in an exposure time of 72 hours. The same concentration may also reduce the number of live cells at rates up to $85 \%$ in the same time of exposure. Lowered effect observed in cell lines that are hormone-dependent, cases such as breast and prostate cancer.

\section{Conclusions}

The MTT viability assays were used to test the hypothesis that combined treatment with Cisplatin and Anvirzel ${ }^{\mathrm{TM}}$ would be more effective than either drug alone. The results of all three assays were both concentration and cell linedependent. It is noteworthy that increased efficacy was observed at lower concentrations of both substances, $0.01 \mathrm{ng} /$ $\mathrm{ml}$ for Anvirzel ${ }^{\mathrm{TM}}$ and $0.1 \mu \mathrm{g} / \mathrm{ml}$ for Cisplatin, than of either drug alone. The results were neither reliable nor reproducible at higher concentrations of Anvirzel ${ }^{\mathrm{TM}}$ and Cisplatin. The results were also time-dependent: treatment was effective after $48 \mathrm{~h}$ and $72 \mathrm{~h}$ of incubation, but not after $24 \mathrm{~h}$.

The present study contributes to demonstrate an effective interaction between Anvirzel ${ }^{\mathrm{TM}}$ and another widely used drug with cytostatic effects. Based on these data, it is crucial to perform further studies to identify and characterize the interaction between Anvirzel ${ }^{\mathrm{TM}}$ and other drugs currently used to treat cancer.

\section{Abbreviations}

CDDP: Cisplatin; MTT: 3-(4,5-Dimethylthiazol-2-yl)-2,3-diphenyltetrazolium bromide; NSCLC: Non-small cell lung cancer.

\section{Competing interests}

The authors declare that they have no competing interests.

\section{Authors' contributions}

PA carried out the chemosensitivity assays, drafted the manuscript and performed the statistical analysis. MT participated in the chemosensitivity assays. MC participated in the chemosensitivity assays. El carried out the cell lines culture. DK participated in the design of the study and coordination. JN participated in the design of the study and coordination. DK participated in the design of the study. IP supervised the assays and the manuscript. All authors read and approved the final manuscript.

\section{Acknowledgements}

The authors thank the two anonymous referees whose valuable commentary allowed us to improve the manuscript.

\section{Author details}

${ }^{1}$ Research Genetic Cancer Centre Ltd (R.G.C.C. Ltd), Filotas, Florina, Greece.

${ }^{2}$ Nerium Biotechnology, Inc. San Antonio, Texas, USA. ${ }^{3}$ Department of Biochemistry \& Biotechnology, University of Thessaly, Larisa, Greece.

Received: 3 August 2012 Accepted: 20 March 2013

Published: 25 March 2013

\section{References}

1. Sreenivasan YSA, Manna SK: Oleandrin suppresses activation of nuclear transcription factor-kappa B and activator protein-1 and potentiates apoptosis induced by ceramide. Biochem Pharmacol 2003, 66:2223-2239.

2. Newman RA, Kondo Y, Yokoyama T, et al: Autophagic cell death of human pancreatic tumor cells mediated by oleandrin, a lipid-soluble cardiac glycoside. Integr Cancer Ther 2007, 6:354-364.

3. Raghavendra PB, Sreenivasan Y, Ramesh GT, Manna SK: Cardiac glycoside induces cell death via FasL by activating calcineurin and NF-AT, but apoptosis initially proceeds through activation of caspases. Apoptosis 2007, 12:307-1318.

4. Frese SF-SM, Andres AC, Miescher D, Zumkehr B, Schmid RA: Cardiac glycosides initiate Apo2L/TRAIL-induced apoptosis in non-small cell lung cancer cells by up-regulation of death receptors 4 and 5 . Cancer Res 2006, 66:5867-5874.

5. Raghavendra PB, Sreenivasan Y, Manna SK: Oleandrin induces apoptosis in human, but not in murine cells: dephosphorylation of Akt, expression of FasL, and alteration of membrane fluidity. Mol Immunol 2007. 44:2292-2302

6. Stenkvist B: Cardenolides and cancer. Anticancer Drugs 2001, 12:635-638.

7. Langford SD, Boor PJ: Oleander toxicity: an examination of human and animal toxic exposures. Toxicology 1996, 109:1-13.

8. Wang X, Plomley JB, Newman RA, Cisneros A: LC/MS/MS analyses of an oleander extract for cancer treatment. Anal Chem 2000, 72:3547-52.

9. Pathak S, Multani AS, Narayan S, Kumar V, Newman RA: Anvirzel, an extract of Nerium oleander, induces cell death in human but not murine cancer cells. Anticancer Drugs 2000, 11:455-63.

10. McConkey DJ, Lin Y, Nutt LK, Ozel HZ, Newman RA: Cardiac glycosides stimulate $\mathrm{Ca} 2+$ increases and apoptosis in androgen-independent, metastatic human prostate adenocarcinoma cells. Cancer Res 2000, 60:3807-3812

11. Smith JA, Madden T, Vijjeswarapu M, Newman RA: Inhibition of export of fibroblast growth factor-2 (FGF-2) from the prostate cancer cell lines PC3 and DU145 by Anvirzel and its cardiac glycoside component, oleandrin. Biochem Pharmacol 2001, 62:469-472.

12. Apostolou P, Toloudi M, Chatziioannou M, Papasotiriou I: Determination of efficacy of Anvirzel ${ }^{\mathrm{TM}}$ in 37 established cancer cell lines. International Pharmaceutical Industry 2011, 3:68-72.

13. Rosenberg B, VanCamp L, Trosko JE, Mansour VH: Platinum compounds: a new class of potent antitumour agents. Nature 1969, 222:385-386.

14. Trzaska S: The top pharmaceuticals that changed the world. C\&EN News 2005, 83:3

15. Stordal B, Davey M: Understanding cisplatin resistance using cellular models. IUBMB Life 2007, 59:696-699.

16. Chen XX, Lai MD, Zhang YL, Huang Q: Less cytotoxicity to combination therapy of 5-fluorouracil and cisplatin than 5-fluorouracil alone in human colon cancer cell lines. World J Gastroenterol 2002, 8:841-846.

17. Alshehri A, Beale P, Yu JQ, Huq F: Synergism from combination of cisplatin and a trans-platinum compound in ovarian cancer cell lines. Anticancer Res 2010, 30:4547-4553.

18. Apostolou P, Toloudi M, Chatziioannou M, Papasotiriou I: Studying the effect of Anvirzel ${ }^{\mathrm{TM}}$, Carboplatin and Docetaxel in NSCLC cell lines. Journal for Clinical Studies 2011, 3:32-34.

19. Liu Y, Peterson DA, Kimura H, Schubert D: Mechanism of cellular 3-(4,5-dimethylthiazol-2-yl)-2,5-diphenyltetrazolium bromide (MTT) reduction. J Neurochem 1997, 69:581-593.

20. Mosmann T: Rapid colorimetric assay for cellular growth and survival: application to proliferation and cytotoxicity assays. J Immunol Methods 1983, 65:55-63.

21. Mickisch G, Fajta S, Keilhauer G, Schlick E, Tschada R, Alken P: Chemosensitivity testing of primary human renal cell carcinoma by a tetrazolium based microculture assay (MTT). Urol Res 1990, 18:131-136. 
22. Sargent JM: The use of the MTT assay to study drug resistance in fresh tumour samples. Recent Results Cancer Res 2003, 161:13-25.

23. Twentyman PR, Luscombe M: A study of some variables in a tetrazolium dye (MTT) based assay for cell growth and chemosensitivity. $\mathrm{Br} J$ Cancer 1987, 56:279-285.

24. Ingle JDJ, Crouch SR: Spectrochemical Analysis. New Jersey: Prentice Hall; 1988

25. Leporatti ML, Posocco E, Pavesi A: Some new therapeutic uses of several medicinal plants in the province of Terni (Umbria, Central Italy). J Ethnopharmacol 1985, 14:65-68.

26. Wolfred MM: The evaluation of the glycoside oleandrin, on the embryo chick heart. J Am Pharm Assoc Am Pharm Assoc 1949, 38:581-584.

27. Manna SK, Sah NK, Newman RA, Cisneros A, Aggarwal BB: Oleandrin suppresses activation of nuclear transcription factor-kappaB, activator protein-1, and c-Jun NH2-terminal kinase. Cancer Res 2000, 60:3838-3847.

28. Chen JQ, Contreras RG, Wang R, et al: Sodium/potassium ATPase ( $\mathrm{Na+}$, K + -ATPase) and ouabain/related cardiac glycosides: A new paradigm for development of anti- breast cancer drugs? Breast Cancer Res Treat 2006, 96:1-15

doi:10.1186/2050-6511-14-18

Cite this article as: Apostolou et al:: Anvirzel ${ }^{\mathrm{TM}}$ in combination with cisplatin in breast, colon, lung, prostate, melanoma and pancreatic cancer cell lines. BMC Pharmacology and Toxicology 2013 14:18.

\section{Submit your next manuscript to BioMed Central and take full advantage of:}

- Convenient online submission

- Thorough peer review

- No space constraints or color figure charges

- Immediate publication on acceptance

- Inclusion in PubMed, CAS, Scopus and Google Scholar

- Research which is freely available for redistribution 